\title{
DESAIN PENDIDIKAN AGAMA DALAM KELUARGA GUNA MEMBANGUN KEMAMPUAN PROBLEM SOLVING ANAK
}

\author{
Kusroh Lailiyah, M. Syamsul Rizal, Farah Dzil Barr \\ Universitas Selamat Sri
}

\begin{abstract}
The purpose of this study is to discuss how to design religious education in the family to build children's problem solving abilities. The location of this research is Pekalongan Utara District, Pekalongan City. The approach in this research uses a descriptive approach, the method used is a combination of qualitative and quantitative methods. A qualitative approach is used to describe trends in religious education, while the quantitative method, namely statistical testing, includes hypothesis testing on signs, hypothesis testing through the khai-squared distribution and hypothesis testing on the median value. Based on the hypothesis testing on the median value, it was found that the type of application of religious education is actually the same through (exemplary, habituation and training, advice, supervision, and punishment). Meanwhile, based on testing the distribution of the khai-squared preference in applying among the applications of religious education, it is actually the same. The qualitative conclusion is that the pattern of religious education in families in Pekalongan Utara District, Pekalongan City, has mostly implemented a permissive pattern, while the design of religious education that is appropriate in order to build problem solving abilities is in accordance with the social conditions in which the adolescent lives.
\end{abstract}

Keywords: Religious education design, parenting style, problem solving

\section{PENDAHULUAN}

Pendidikan adalah usaha sadar dan terencana untuk mewujudkan suasana belajar dan proses pembelajaran agar peserta didik secara aktif mengembangkan potensi dirinya untuk memiliki kekuatan spiritual keagamaan, pengendalian diri, kepribadian, kecerdasan, akhlak mulia, serta keterampilan yang diperlukan dirinya, masyarakat, bangsa dan negara (Dewantara, (tt)). Ada tiga jalur dalam Undang-Undang No. 20 tahun 2003 yaitu, jalur pendidikan formal, nonformal, dan informal. jalur informal adalah pendidikan keluarga dan lingkungan (Munawiroh, 2016).

Pendidikan agama di lingkungan keluarga sangat besar peranannya dalam pembentukan kepribadian bagi anak-anak, karena di lingkungan keluargalah anak-anak pertama kali menerima pendidikan yang dapat mempengaruhi perkembangan anak selanjutnya. Agar anak-anak memiliki kepribadian yang baik dan terhindar dari pelanggaran-pelanggaran moral, maka perlu adanya pembinaan agama sejak dini kepada anak-anak dalam keluarga. Proses pembinaan nilai-nilai agama dalam membentuk kepribadian aak-anak dapat dimulai sejak anak lahir sampai ia dewasa (Fachrudin, 2011). Pada umumnya pendidikan Islam dalam keluarga dilakukan dengan menanamkan nilai-nilai agama Islam, yakni etika yang meliputi akhlak, budi perkerti, dan tingkah laku yang harus dilakukan dalam kehidupan sehari-hari (Andriyani, 2012). Orang tua memegang peranan yang sangat penting dalam pembentukan kepribadian bagi anak-anaknya. Baik buruknya kepribadian anak-anak di masa yang akan datang banyak ditentukan oleh pendidikan dan bimbingan orang tuanya.

Sejalan dengan semakin pesatnya arus globalisasi yang dicirikan dengan derasnya arus informasi dan teknologi ternyata dari satu sisi memunculkan persoalan-persoalan baru yang kerap kita temukan pada diri individu dalam suatu masyarakat. Munculnya kenakalan remaja, tawuran antar pelajar, narkoba, penyimpangan seksual, kekerasan serta berbagai bentuk penyimpangan penyakit 
kejiwaan, seperti stres, depresi, dan kecemasan, adalah bukti yang tak ternafikan dari adanya dampak negatif dari kemajuan peradaban kita. Hal ini kemudian secara tidak langsung berpengaruh tidak baik pula pada kemapanan dan tatanan masyarakat damai seperti kita semua harapkan.

Faktor-faktor yang menyebabkan anakanak memiliki kepribadian buruk menurut Darajat (2010) antara lain: (1) kurang tertanamnya jiwa agama pada tiap-tiap orang dalam masyarakat; (2) keadaan masyarakat yang kurang stabil, baik dari segi ekonomi, sosial, dan politik; (3) pendidikan moral tidak terlaksana menurut mestinya, baik di rumah tangga, sekolah maupun masyarakat; (4) suasana rumah tangga yang kurang baik; (5) diperkenalkannya secara populer obat-obat dan alat-alat anti hamil; (6) banyaknya tulisantulisan, gambar-gambar, siaran-siaran, kesenian-kesenian yang tidak mengindahkan dasar-dasar dan tuntunan moral; (7) kurang adanya bimbingan untuk mengisi waktu luang (leisure time) dengan cara yang baik, dan yang membawa kepada pembinaan moral; dan (8) tidak ada atau kurangnya markas-markas bimbingan dan penyuluhan bagi anak-anak dan pemuda-pemuda.

Parawansa (2014) menyatakan bahwa penyalahgunaan narkoba, tawuran antar pelajar dan seks bebas, ini menunjukkan peran pendidikan agama dalam keluarga belum sepenuhnya dilakukan oleh orang tua. Hal itu disebabkan karena lemahnya kontrol dan prinsip keteladanan orang tua tidak terbangun sejak dini.

Problem solving berasal dari bahasa asing yang terdiri dari dua buah kata, yakni problem dan solving. Problem artinya masalah atau permasalahan. Sedangkan solving berasal dari kata solve yaitu memecahkan atau pemecahan (Yusri \& Maris, 2017). Problem solving seperti yang diartikan Syaiful Bahri Djamarah dan Aswan Zain adalah suatu cara berpikir secara ilmiah untuk mencari pemecahan suatu masalah (Bahri, 2002). Pemecahan masalah adalah suatu proses berpikir sebagai upaya dalam menemukan suatu masalah dan memecahkannya berdasarkan informasi yang dikumpulkan dari berbagai sumber sehingga dapat diambil suatu kesimpulan yang tepat (Argusni \& Sylvia, 2019).

Beberapa penelitian yang terkait dengan penelitian ini adalah sebagai berikut. Penelitian yang dilakukan oleh Mohammad Ulyan (2020) menyimpulkan bahwa pendidikan keluarga sebagai salah satu pendidikan informal yang sangat penting bagi anak. Pendidikan akhlak dalam mengatasi degradasi kejujuran dapat dilakukan dengan uswatun hasanah, pemberian contoh, pembiasaan, bimbingan, nasihat, tarhib dan targhib. Penelitian yang dilakukan oleh Musmualim \& Muhammad Miftah (2018) menyimpulkan menurut pemikiran Hasan Langgulung keluarga sebagai unit sosial yang menjadi tempat pendidikan pertama dalam penanaman nilai-nilai dan pewarisan budaya kepada generasi masyarakat. Penelitian Taufiqur Rohman (2018) menyimpulkan bahwa problematika pendidikan agama dalam kelurga muslim di Desa Pulutan Kecamatan Sidorejo Kota Salatiga disebabkan oleh beberapa faktor, yaitu faktor kurangnya perhatian dari orang tua dan faktor keteladanan dari orang tua serta minat anak yang kurang dalam mempelajari agama Islam. Hasil penelitian Aulia Rahmi (2018) menyatakan pendidikan agama bagi anak dalam keluarga di Gampong Aneuk Galong Baro dimulai juga dengan pendidikan akidah, karena akidah merupakan inti dari dasar keimanan seseorang yang harus ditanamkan kepada anak sejak dini. Selanjutnya dengan pendidikan ibadah, dalam pendidikan ibadah orang tua lebih memfokuskan kepada ibadah shalat, mengaji juga puasa. Terakhir orang tua mengajarkan anaknya tentang akhlak karena hasil dari keimanan dan ibadah yang baik dapat terlihat dalam akhlak sehari-hari. Penelitian yang dilakukan Mardiyah (2015) menghasilkan demi tercapainya pembentukan kepribadian yang baik, maka pendidikan agama hendaknya diberikan orang tua yang benar-benar tercermin agama dalam sikap, tingkah laku, gerak-gerik, cara berpakaian, cara berbicara, cara menghadapi persoalan dan dalam keseluruhan pribadinya. Dengan singkat dapat dikatakan bahwa pendidikan agama akan sukses apabila ajaran agama itu hidup dan tercermin dalam pribadi orang tua itu sendiri. 
Dari beberapa penelitian di atas, penelitian ini merupakan penelitian pelengkap. Beberapa penelitian yang telah disebutkan di atas hanya memaparkan cara-cara pendidikan agama dalam keluarga sedangkan penelitian yang dilakukan oleh peneliti lebih mendalam lagi yaitu menyajikan desain pendidikan agama dalam keluarga untuk membangun kemampuan problem solving pada remaja yang disesuaikan dengan karakterisik linkungan di mana remaja tersebut tinggal.

Kota Pekalongan masuk dalam 10 besar kota narkoba dari 35 kota se-Jawa Tengah. Pada tahun 2016, data kasus narkoba anak di bawah umur di Kota Pekalongan ada 22 kasus kemudian meningkat menjadi 30 kasus di tahun 2017.

Sedangkan di awal 2018 sampai pertengahan Mei 2018 ini, ada 15 kasus narkoba untuk anak di bawah umur. Selama tahun 2019, Satuan Reserse Narkoba Polres Pekalongan Kota mengungkap 63 kasus peredaran dan atau penyalahgunaan narkotika dan obat-obatan terlarang (narkoba) di wilayah hukum Polres Pekalongan Kota. Kepolisian Resor Pekalongan Kota, Jawa Tengah, pada tanggal 1 Agustus 2020 membekuk empat tersangka narkotika dan obat berbahaya dengan barang bukti 3,5 gram sabu, 2,5 gram ganja, alat hisap, pipet, dan korek api. Sebelumnya pada akhir Januari 2020 Kepolisian Resor Pekalongan Kota juga meringkus dua tersangka kasus narkotika dan obat berbahaya sekaligus mengamankan 0,68 gram, 5 bungkus plastik klip sabu sisa pakai, alat hisap sabu, 9 korek api gas, 2 pipet, 2 skrap, dan 1 ponsel (jateng.antaranews.com). Meningkatnya kasus kenakalan remaja di Kota Pekalongan tersebut menjadi tanggung jawab bersama antara pemerintah daerah tetapi juga seluruh elemen masyarakat.

Dilihat dari bidang sosial Kecamatan Pekalongan Utara menghadapi permasalahan masih banyaknya penyandang masalah kesejahteraan sosial sehingga berdampak kepada banyaknya anak dan remaja nakal, penyalahgunaan narkoba, meningkatnya angka kejahatan dan kriminalitas. Dilihat dari bidang pendidikan Kecamatan Pekalongan Utara menghadapi permasalahan rendahnya kesadaran pentingnya pendidikan sehingga berdampak kepada banyaknya anak putus sekolah, perubahan perilaku anak, banyaknya anak jalanan.

Sesuai dengan misi Pemerintah Kota Pekalongan untuk mengembangkan tata kehidupan bermasyarakat yang berakhlaqul karimah tentu persoalan kenakalan remaja di Kota Pekalongan ini harus menjadi perhatian untuk mendapatan penanganan yang maksimal. Selain peran dari pemerintah daerah dan seluruh elemen masyarakat, peran keluarga menempati posisi terpenting untuk membentengi kenakalan remaja. Pola pendidikan keluarga dan agama yang baik, dapat mencegah kenakalan remaja yang menjurus pada kriminalitas dan penyalahgunaan obat-obat terlarang. Oleh karenanya, penelitian ini bertujuan untuk mengetahui pola pendidikan agama di Kecamatan Pekalongan Utara dan untuk menemukan desain pendidikan agama dalam keluarga yang tepat guna membangun kemampuan problem solving anak agar tindak kenakalan remaja dapat dihindarkan.

\section{TINJAUAN PUSTAKA}

\subsection{Kenakalan Remaja}

Kenakalan remaja dapat dikatakan sebagai salah satu problem sosial yang perlu mendapatkan perhatian dari semua pihak terkait. Sunarwiyati (dalam Unayah dan Sabarisman, 2015) membagi kenakalan remaja ke dalam tiga tingkatan, yaitu: (1) kenakalan biasa, seperti suka berkelahi, suka berkeluyuran, membolos sekolah, pergi dari rumah tanpa pamit; (2) kenakalan yang menjurus pada kejahatan dan pelanggaran seperti mengendarai motor tanpa kelengkapan surat, mengembil barang orang tua dan orang lain tanpa izin; (3) kenakalan khusus seperti penyalahgunaan narkoba, hubungan seks bebas dan pencurian.

\subsection{Pendidikan Agama dalam Keluarga}

Menurut Baumrid, (2004) ada 4 jenis pola pendidikan agama orang tua terhadap anak: Pertama, Pola Otoriter. Ciri pola ini menekankan segala aturan orang tua harus ditaati oleh anak. Orang tua bertindak semenamena, tanpa dapat dikontrol oleh anak. Anak 
harus menurut dan tidak boleh membantah terhadap apa yang diperintahkan oleh orang tua. Kedua, Pola Permisif. Sifat pola permisif adalah segala aturan dan ketetapan keluarga di tangan anak. Apa yang dilakukan oleh anak diperbolehkan orang tua, orang tua menurut segala kemauan anak. Ketiga, Pola Demokrasi. Kedudukan antara anak dan orang tua sejajar. Suatu keputusan diambil bersama dengan mempertimbangkan kedua belah pihak. Anak diberi kebebasan yang bertanggung jawab, artinya apa yang dilakukan oleh anak tetap harus di bawah pengawasan orang tua dan dapat dipertanggungjawabkan secara moral. Keempat, Pola Situasional. Orang tua yang menerapkan pola asuh ini, tidak berdasarkan pada pola asuh tertentu, tetapi semua tipe tersebut diterapkan secara luwes disesuaikan dengan situasi dan kondisi yang berlangsung saat itu.

Adapun pendidikan agama yang diterapkan dalam keluarga dalam penelitian ini sebagai berikut:

a) Memberikan dorongan dan nasihat yang baik kepada anak.

b) Membimbing melakukan pembiasaanpembiasaan pengamalan agama di lingkungan keluarga

c) Menerapkan reward and punishment; yaitu hukuman dan penghargaan yang sesuai dengan tahap perkembangan jiwa anak.

d) Memberikan keteladanan; sebagai orang tua tentunya harus menjadi teladan baik bagi anak-anaknya.

e) Memanjatkan doa demi kebaikan dan kesalehan anak-anak kita.

\subsection{Problem Solving}

Problem solving merupakan salah satu aspek kemampuan berpikir kritis yang perlu dikembangkan pada setiap individu. Kemampuan problem solving merupakan kemampuan intelektual yang bersifat komplek, yaitu kemampuan memahami konsep-konsep dan kaidah-kaidah dalam memecahkan masalah yang dihadapi. Problem solving adalah landasan belajar anak, kemampuan tersebut harus dihargai. Oleh sebab itu, menumbuhkan kemampuan problem solving yang paling tepat adalah pada masa anak-anak dan sedini mungkin. Anak-anak didorong untuk memikirkan solusi dan alternaif terhadap masalah, yang akan membantu mereka lebih percaya diri ketika mereka menghadapi situasi sulit. Anak-anak yang belajar pemecahan masalah (problem solving) akan mengembangkan dan menggunakan kemampuan mereka sepanjang hidup.

\section{METODE PENELITIAN}

Penelitian ini dilaksanakan di Kecamatan Pekalongan Utara, Kota Pekalongan. Jenis penelitian ini adalah penelitian lapangan. Pendekatan dalam penelitian ini menggunakan pendekatan deskriptif sedangkan metode yang digunakan adalah metode kombinasi antara kualitatif dan kuantitatif. Pendekatan kualitatif digunakan untuk mendeskripsikan tentang trend pendidikan agama, adapun metode kuantitatif yaitu uji statistik meliputi pengujian hipotesis atas tanda, pengujian hipotesis melalui distribusi khai-kuadrat dan pengujian hipotesis atas nilai median.

Populasi yang digunakan dalam penelitian ini adalah seluruh remaja yaitu anak rentan usia 12-18 tahun (Hurlock, 1981) dan keluarga seKecamatan Pekalongan Utara. Prosedur pengambilan sampel pada penelitian ini adalah secara purposive sampling. Pengolahan data dilakukan secara kualitatif deskriptif yaitu dengan menggunakan bebe rapa metode sebagai berikut:

a) Reduksi data yaitu memilih data yang terkumpul dan mendukung melalui pengkategorian data yang diperlukan peneliti dan tidak diperlukan.

b) Penyajian data yaitu peneliti berusaha menyusun data yang relevan sehingga menjadi informasi yang dapat disimpulkan dan memiliki makna tertentu.

c) Verifikasi data yaitu peneliti menarik kesimpulan berdasarkan temuan dan melakukan triangulasi di antara hasil pengamatan.

Untuk pengolahan data secara kuantitaif digunakan beberapa uji statistik yaitu :

a) Pengujian hipotesis atas tanda.

b) Pengujian hipotesis melalui distribusi khaikuadrat.

c) Pengujian hipotesis terhadap nilai median.

Uji validitas data dilakukan peneliti dengan menggunakan teknik triangulasi. 
Triangulasi yang digunakan peneliti ada tiga jenis yaitu: triangulasi sumber, triangulasi waktu dan triangulasi data. Artinya, peneliti akan mengolah data hasil penelitian dengan mengulang dan mengevaluasi berdasarkan data, sumber dan waktu yang berbeda. (Sugiyono, 2015)

\section{HASIL}

Analisis data dilakukan setelah data dari seluruh responden terkumpul. Data yang diperoleh berupa angket yang telah diisi, hasil wawancara, hasil observasi, dan dokumentasi.

\subsection{Kuesioner}

Kuesioner yang disusun dalam penelitian ini ada 2 (dua). Kuesioner pertama merupakan angket desain pendidikan agama dalam keluarga yang diperuntukkan untuk anak usia remaja. Sedangkan kuesioner yang kedua merupakan angket desain pendidikan agama dalam keluarga yang diperuntukkan untuk orang tua. Sebelum menyusun kuesioner, terlebih dahulu peneliti melakukan Focus Group Discussion (FGD) untuk menentukan indikator dan kisi-kisi instrumen. Draf angket bagi anak yang disusun peneliti sebanyak 50 butir. Angket untuk orang tua sebanyak 50 butir.

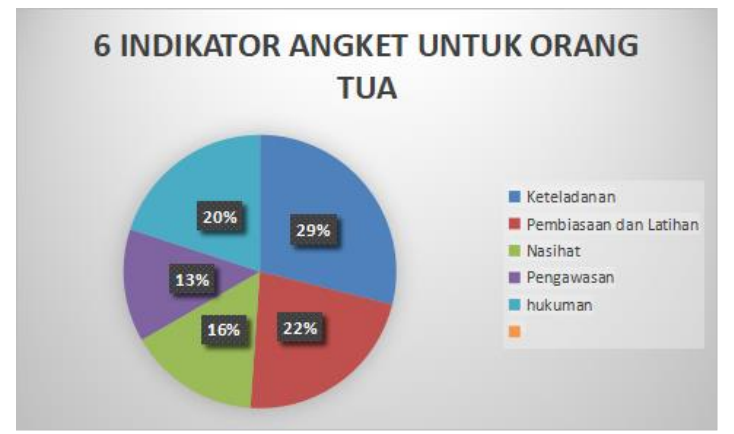

Gambar 1 Grafik Indikator Angket untuk Responden Orang Tua

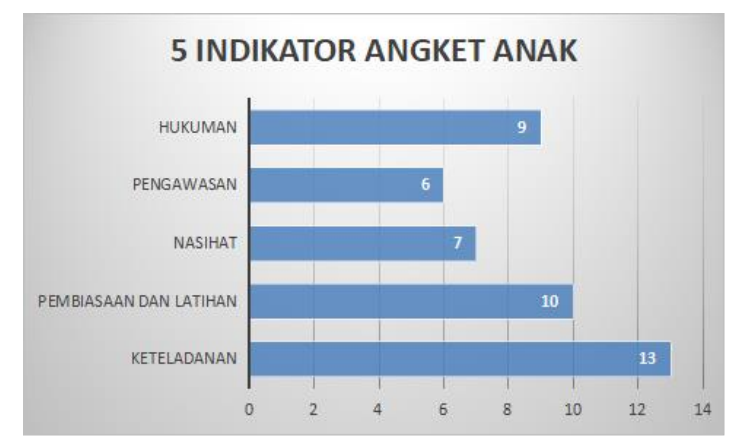

Gambar 2 Grafik Indikator Angket Responden Anak
Analisis data dari kuesioner dilakukan setelah data dari seluruh responden terkumpul. Responden yang mengisi angket adalah sebanyak 220 orang yang terdiri dari 110 keluarga. Keluarga dengan anak yang berprestasi sebayak 30, selanjutnya disebut keluarga tipe-0. Keluarga dengan anak kategori kenakalan biasa sebanyak 42, selanjutnya disebut keluarga tipe-1. Keluarga dengan anak kategori kenakalan yang menjurus pada kejahatan dan pelanggaran sebanyak 33, selanjutnya disebut keluarga tipe-2 Keluarga dengan anak kategori kenakalan khusus sebanyak 3, selanjutnya disebut keluarga tipe-3.

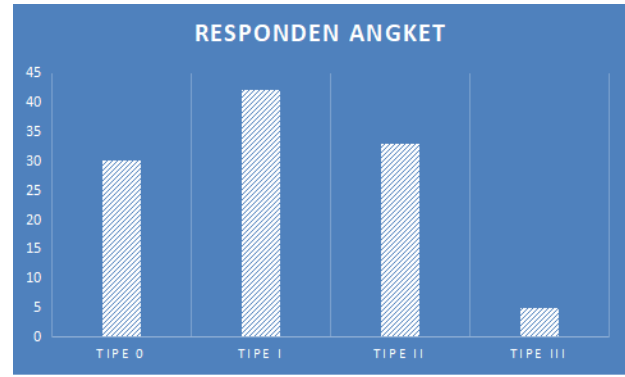

Gambar 3 Grafik Responden Angket

Teknik analisis yang dilakukan adalah teknik statistik deskriptif. Statistik deskriptif adalah statistik yang digunakan untuk menganalisis data dengan cara mendeskripsian atau menggambarkan data yang telah terkumpul sebagaimana adanya tanpa bermaksud membuat kesimpulan yang berlaku untuk umum atau generalisasi (Sugiyono, 2015). Adapun tekniknya adalah persentase dan penentuan data kategoris dari data yang diperoleh dengan rumus sebagai berikut.

\subsubsection{Persentase}

Mencari persentase adalah untuk mengetahui status yang dipersentasekan dan disajikan tetap berupa persentase (Arikunto, 2010). Persentase untuk jawaban masingmasing item pernyataan dapat diperoleh dengan cara membagi jumlah skor yang diperoleh dengan jumlah skor ideal, kemudian dikalikan dengan $100 \%$ atau dengan rumus sebagai berikut:

$$
P=\frac{\text { Jumlah_skor_yang_diperoleh }}{\text { Jumlah_skor_ideal }} \times 100 \%
$$

Keterangan:

$$
\begin{array}{ll}
P & =\text { Persentase } \\
\text { Jumlah Skor Ideal } & =\mathrm{N} \times \text { bobot tertinggi } \\
\mathrm{N} & =\text { Jumlah responden }
\end{array}
$$


Hasil dari perolehan persentase untuk masing-masing item pernyataan kemudian dikonsultasikan dalam skala sikap sebagai berikut:

Tabel 1 Persentase Skala Sikap

\begin{tabular}{cc}
\hline Hasil Persentase & Skala Sikap \\
\hline$P=0$ & Tidak Seorangpun \\
$0<P<25 \%$ & Sebagian Kecil \\
$25 \%<P<50 \%$ & Hampir Setengahnya \\
$P=50 \%$ & Setengahnya \\
$50 \%<P<75 \%$ & Hampir Sebagian Besar \\
$75 \%<P<100 \%$ & Sebagian Besar \\
$P=100 \%$ & Seluruhnya \\
\hline
\end{tabular}

\subsubsection{Penentuan data kategoris}

Data kategoris digunakan untuk mengukur sikap, pendapat, dan persepsi seseorang atau kelompok orang tentang fenomena sosial (Sugiyono: 2015). Alternatif jawaban yang digunakan dalam kuesioner penelitian ini hanya empat, yaitu Sangat Setuju, Setuju, Tidak Setuju, Sangat Tidak Setuju. Sehingga bentuk skor nya menjadi sebagai berikut.

Tabel 2 Persentase Skala Sikap

\begin{tabular}{ccc}
\hline Sangat Setuju & 4 & 1 \\
Setuju & 3 & 2 \\
Sangat Tidak Setuju & 2 & 3 \\
Sangat Tidak Setuju & 1 & 4 \\
\hline
\end{tabular}
berikut.

Ringkasan hasil angket adalah sebagai

Keluarga tipe-0 sebesar 89,3\% menerapkan keteladanan atau mencontohkan dalam mendidik anak, $88,6 \%$ pembiasaan dan latihan, $88,8 \%$ nasihat, $88,2 \%$ pengawasan, $85,5 \%$ hukuman, dan $87,5 \%$ mendoakan.

Keluarga tipe-1 sebesar 92,4\% menerapkan keteladanan atau mencontohkan dalam mendidik anak, $91,7 \%$ pembiasaan dan latihan, $92 \%$ nasihat, $92,4 \%$ pengawasan, $88 \%$ hukuman, dan $86,9 \%$ mendoakan.
Keluarga tipe-2 sebesar 85,2\% menerapkan keteladanan atau mencontohkan dalam mendidik anak, $86,6 \%$ pembiasaan dan latihan, $85,4 \%$ nasihat, $83,9 \%$ pengawasan, $82,1 \%$ hukuman, dan $84,8 \%$ mendoakan.

Keluarga tipe-3 sebesar 68,8\% menerapkan keteladanan atau mencontohkan dalam mendidik anak, $67 \%$ pembiasaan dan latihan, 64\% nasihat, 63\% pengawasan, 62\% hukuman, dan $71 \%$ mendoakan.

Untuk kasus dalam penelitian ini, hipotesis nihil menyatakan bahwa preferensi tipe keluarga terhadap jenis pendidikan agama adalah sama. Sedangkan hipotesis alternatifnya menyatakan bahwa preferensi tipe keluarga terhadap jenis pendidikan agama adalah berbeda. Secara simbolis, formula hipotesis nihil dan alternatif dalam penelitian kasus ini dirumuskan sebagai berikut

Ho : Tipe keluarga memiliki preferensi yang sama terhadap jenis pendidikan agama

H1 : Tipe keluarga memiliki preferensi yang berbeda terhadap setiap jenis pendidikan agama

Pada kasus ini, taraf signifikansi yang diberlakukan adalah sebesar 2,50\% atau 0,025. Dari deskripsi kasus ini, jenis pendidikan agama adalah 6. Dengan demikian, derajat kebebasan yang diberlakukan adalah 5(6-1). Dengan demikian, nilai khai-kuadrat dalam tabel untuk taraf signifikansi $2,50 \%$ serta derajat kebebasan 5 adalah 12,832. Karena itulah, kriteria pengujian yang diberlakukan adalah bahwa hipotesis nihil diterima apabila

$$
X^{2} \leq 12,832
$$

Sedangkan hipotsis nihil akan ditolak jika

$$
X^{2} \geq 12,832
$$

Adapun tabel distribusi frekuensi yang ditampilkan terkait kasus ini adalah sebagai berikut.

\begin{tabular}{|c|c|c|c|c|c|c|}
\hline Keluarga & Keteladanan & $\begin{array}{l}\text { Pembiasaan } \\
\text { dan Latihan }\end{array}$ & Nasihat & Pengawasan & Hukuman & Mendoakan \\
\hline Tipe-0 & 89,3 & 88,6 & 88,8 & 88,2 & 85,5 & 87,5 \\
\hline \multirow[t]{2}{*}{ Tipe-1 } & 92,4 & 91,7 & 92 & 92,4 & 88 & 86,9 \\
\hline & 91 & 91 & 91 & 91 & 91 & 91 \\
\hline Tipe-2 & 85,2 & 86,6 & 85,4 & 83,9 & 82,1 & 84,8 \\
\hline \multirow[t]{2}{*}{ Tipe-3 } & 68,8 & 67 & 64 & 63 & 62 & 71 \\
\hline & 66 & 66 & 66 & 66 & 66 & 66 \\
\hline
\end{tabular}

Tabel 3 Distribusi Frekuensi 
Sesudah itu, nilai khai-kuadrat kita hitung. Besarnya nilai khai kuadrat adalah:

Nilai khai-kuadrat untuk keluarga tipe-0: $\frac{(89,3-88)^{2}}{88}+\frac{(88,6-88)^{2}}{88}+\frac{(88,8-88)^{2}}{88}+\frac{(88,2-88)^{2}}{88}+\frac{(85,5-88)^{2}}{88}$ $+\frac{(87,5-88)^{2}}{88}=0,10$

Nilai khai-kuadrat untuk keluarga tipe-1 $\frac{(92,4-91)^{2}}{91}+\frac{(91,7-91)^{2}}{91}+\frac{(92-91)^{2}}{91}+\frac{(92,4-91)^{2}}{91}+\frac{(88-91)^{2}}{91}$ $+\frac{(86,9-91)^{2}}{91}=0,33$

Nilai khai-kuadrat untuk keluarga tipe-2 $\frac{(85,2-85)^{2}}{85}+\frac{(86,6-85)^{2}}{85}+\frac{(85,4-85)^{2}}{85}+\frac{(83,9-85)^{2}}{85}+\frac{(82,1-85)^{2}}{85}$ $+\frac{(84,8-85)^{2}}{85}=0,14$

Nilai khai-kuadrat untuk keluarga tipe-3 $\frac{(688-66)^{2}}{66}+\frac{(67-66)^{2}}{66}+\frac{(64-66)^{2}}{66}+\frac{(63-66)^{2}}{66}+\frac{(62-66)^{2}}{66}$ $+\frac{(71-66)^{2}}{66}=0,95$

Dari perhitungan yang telah dilakukan, nilai khai-kuadrat untuk masing-masing tipe keluarga adalah sebesar 0,10, 0,33, 0,14, 0,95. Nilai tersebut lebih kecil daripada nilai dalam tabel. sehingga, hipotesis nihil yang menyatakan bahwa preferensi tipe keluarga terhadap jenis pendidikan agama adalah sama bisa diterima. Sedangkan hipotesis alternatif yang menyatakan bahwa preferensi tipe keluarga terhadap jenis pendidikan agama adalah berbeda ditolak.

Berdasarkan hasil pengujian Goodness of Fit maka disimpulkan bahwa setiap tipe keluarga baik tipe-0, tipe-1, tipe-2, tipe-3 di Kecamatan Pekalongan Utara memiliki preferensi yang sama dalam pendidikan agama anak, yaitu pendidikan agama di keluarga diterapkan dengan melalui 6 hal yaitu mendidik dengan keteladanan, mendidik dengan adab pembiasaan dan latihan, mendidik dengan nasihat, mendidik dengan pengawasan, pemberian hukuman pada anak dan mendoakan. Keluarga tidak mempunyai kecenderungan terhadap salah satu hal pendidikan agama anak tersebut. 6 hal dalam pendidikan agama tersebut dilakukan dengan sama baiknya.

Asumsi bahwa nilai median terhadap jenis penerapan pendidikan agama sebenarnya adalah sama. Dugaan ini dijadikan bentuk hipotesis nihil pada kasus penelitian ini. Sedangkan hipotesis alternatifnya menyatakan bahwa nilai median terhadap jenis penerapan pendidikan agama sebenarnya adalah berbeda. Dengan demikian, formula hipotesis nihil dan hipotesis alternatifnya adalah:

Ho : $\operatorname{Md}_{\text {Keteladanan }}=M d_{\text {Pembiasaan dan latihan }}=$ $\operatorname{Md}_{\text {Nasihat }}=M d_{\text {Pengawasan }}=M d_{\text {Hukuman }}=$ $\mathrm{Md}_{\text {Mendoakan }}$

$\mathrm{Ha}: \operatorname{Md}_{\text {Keteladanan }} \neq \operatorname{Md}_{\text {Pembiasaan dan latihan }} \neq$ $\operatorname{Md}_{\text {Nasihat }} \neq \operatorname{Md}_{\text {Pengawasan }} \neq \operatorname{Md}_{\text {Hukuman }} \neq$ $\mathrm{Md}_{\text {Mendoakan }}$

Dalam kasus ini, taraf signifikansi ditentukan sebesar 5\% atau 0,05. Sementara derajat kebebasan baris adalah 3(4-1) dan derajat kebebasan kolom adalah 5(6-1). Sehingga, derajat kebebasan secara keseluruhannya adalah $15(3 \times 5)$. Apabila taraf signifikansi yang diberlakukan adalah 5\% dan derajat kebebasannya adalah 15 , nilai khaikuadrat dalam tabel distribusinya adalah sebesar 24,996.

\subsection{Data Wawancara}

Wawancara digunakan untuk mengidentifikasi pola pendidikan agama dalam keluarga di Kecamatan Pekalongan Utara, Kota Pekalongan. Pedoman wawancara dengan rincian sebagai berikut: pedoman wawancara untuk orang tua terdiri dari 13 pertanyaan; wawancara dilakukan pada 2 subyek orang tua dari keluarga tipe-1, 2 subyek orang tua keluarga tipe-2, dan 2 subyek orang tua keluarga tipe-3. Wawancara juga dilakukan kepada beberapa tokoh masyarakat dan lingkungan sekolah. Pedoman wawancara untuk tokoh agama terdiri dari 9 pertanyaan, pedoman wawancara untuk pemerintah kelurahan terdiri dari 8 pertanyaan dan pedoman wawancara untuk guru BK terdiri dari 12 pertanyaan.

Dari hasil wawancara di atas dapat disimpulkan bahwa masih banyaknya kenakalan remaja yang terjadi di Kecamatan Pekalongan Utara salah satunya disebabkan oleh pola pendidikan agama yang diberikan oleh orang tua terhadap anaknnya. Hal-hal yang seharusnya dilakukan oleh orang tua untuk menguatkan pendidikan agama dalam keluarga juga tidak dilakukan sehingga kenakalan remaja di Pekalongan Utara masih kerap terjadi.

Berdasarkan hasil wawancara kemudian dilakukan pengujian hipotesis atas tanda 
terhadap jawaban yang diberikan untuk menjawab apakah pendidikan Agama meningkatkan kemampuan problem solving anak. Berdasarkan pengujian hipotesis atas tanda dari wawancara yang telah dilakukan, diperoleh informasi mengenai bagaimana pendidikan agama mampu meningkatkan kemampuan problem solving anak, dalam artian apakah menjadi meningkat atau malah menurun. Informasi mengenai hal ini ditampilkan dalam tabel berikut di mana dalam tabel juga telah dicantumkan dampak desain pendidikan agama bagi masing-masing anak dampak yang terjadi ditandai dengan tanda positif (+) dan negatif (-).

\section{Tabel 4 Pengujian Hipotesis atas Tanda}

\begin{tabular}{ccc}
\hline No. & Dampaknya Terhadap Motivasi & Tanda \\
\hline 1 & Meningkat & + \\
2 & Menurun & - \\
3 & Meningkat & + \\
4 & Meningkat & + \\
5 & Meningkat & + \\
6 & Meningkat & + \\
7 & Meningkat & + \\
8 & Meningkat & + \\
9 & Meningkat & + \\
10 & Menurun & - \\
11 & Meningkat & + \\
12 & Meningkat & + \\
13 & Meningkat & + \\
14 & Meningkat & + \\
15 & Meningkat & + \\
\hline
\end{tabular}

\subsection{Data Observasi (OB)}

Observasi yang dilakukan dalam penelitian ini berfokus kepada orang tua yang memiliki anak dengan catatan kenakalan remaja baik kategori biasa, menjurus pada kejahatan maupun kategori kenakalan khusus yaitu penyalahgunaan narkoba dan seks bebas.

Hasil observasi yang dilakukan oleh tim peneliti menunjukkan bahwa:

Berdasarkan hasil observasi tersebut dapat ditemukan bahwa pendidikan agama dalam keluarga sangat berpengaruh terhadap perilaku anak. Anak yang berasal dari keluarga dengan pendidikan agama yang kurang baik berpotensi besar menjadikan sang anak memiliki karaker yang kurang baik pula dan riskan terlibat kenakalan.

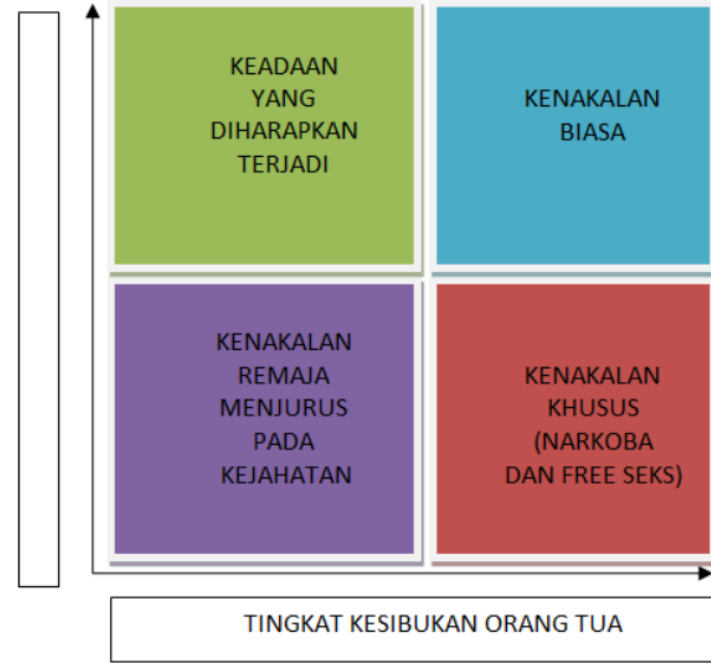

Gambar 4 Matrix Tingkat Pendidikan Agama Terhadap Kategori Kenakalan Remaja

\section{PEMBAHASAN}

5.1. Pola Pendidikan Agama dalam Keluarga di Kecamatan Pekalongan Utara

Berdasarkan analisis data yang telah dilakukan, hasil dari penelitian ini adalah sebagian besar dari responden telah menerapkan pola pendidikan agama dalam keluarganya. Hal ini dibuktikan dengan ratarata hasil persentase yang menunjukkan lebih dari $75 \%$ telah memberikan contoh dan teladan kepada anak, memberikan pembiasaan dan latihan, nasihat, pengawasan, pemberian prestasi dan hukuman serta mendoakan anaknya.

Perbedaan terletak pada keluarga yang mempunyai anak dengan kategori kenakalan biasa dan kenakalan yang menjurus pada kejahatan dan pelanggaran persentasenya di antara $75 \%$ dan $99 \%$. Artinya sebagian besar telah memberikan contoh dan teladan kepada anak, memberikan pembiasaan dan latihan, nasihat, pengawasan, pemberian prestasi dan hukuman serta mendoakan anaknya. Namun pada keluarga yang mempunyai anak dengan kenakalan khusus hasil persentasenya di antara $50 \%$ dan $75 \%$. Artinya hanya hampir sebagian besar yang memberikan contoh dan teladan kepada anak, memberikan pembiasaan dan latihan, nasihat, pengawasan, pemberian prestasi dan hukuman serta mendoakan anaknya. 
Persentase pendidikan agama dalam keluarga yang mempunyai anak dengan kategori berprestasi lebih kecil dari pada pendidikan agama dalam keluarga yang mempunyai anak dengan kategori kenakalan biasa. Pada kenakalan kategori biasa dipengaruhi oleh faktor lain misalnya lingkungan. Pendidikan agama dalam keluarga merupakan sesuatu yang paling penting dan utama meski ada faktor dari pengaruh lingkungan. Seperti studi Hambali dan Arifin, S. pada tahun 1994 membuktikan bahwa kenakalan remaja di wilayah Jawa Timur disebabkan oleh kondisi keluarga yang negatif, seperti ketegangan keluarga, tingkat otoritas orang tua, dan miskinnya teladan keagamaan.

Dari hasil penelitian yang dilakukan oleh tim peneliti menghasilkan sebuah kesimpulan bahwa pola pendidikan agama dalam keluarga yang dilakukan oleh mayoritas keluarga di Kecamatan Pekalongan Utara adalah pola permisif. Sifat pola permisif adalah segala aturan dan ketetapan keluarga di tangan anak. Apa yang dilakukan anak diperbolehkan oleh orang tua. Padahal peran orang tua dalam pembentukan karakter anak adalah peran yang vital. Oleh karenanya, seharusnya orang tualah yang memiliki kendali terhadap kehidupan anaknya, bukan sebaliknya.

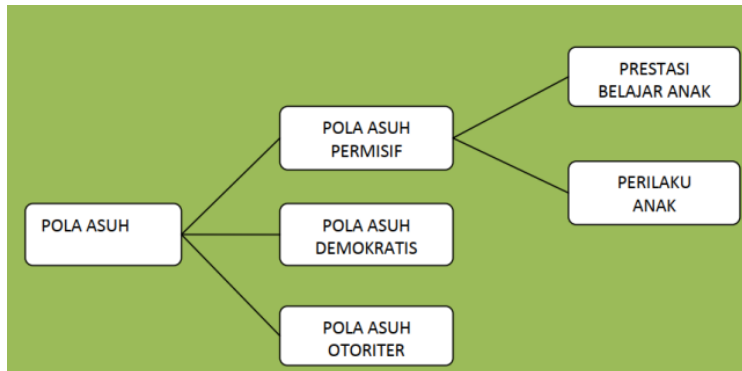

Gambar 5 Pola Asuh Mayoritas Keluarga di Kecamatan Pekalongan Utara

Masih banyaknya tindak kenakalan remaja disebabkan karena anak kurang mendapatkan teladan dari figur orang tua dalam hal pendidikan agama, sehingga anak memiliki kemampuan problem solving yang rendah. Peran orang tua adalah peran tinglah laku, tuladha, atau teladan, dan pola-pola hubungannya dengan anak yang dijiwai dan disemangati oleh nilai-nilai keagamaan secara menyeluruh. Di sinilah lebih-lebih akan terbukti benarnya pepatah, "Bahasa perbuatan adalah lebih fasih dari pada bahasa ucapan". Jadi jelas pendidikan agama menuntut tindakan percontohan lebih banyak dari pada pengajaran verbal. Dengan meminjam istilah yang populer di masyarakat (tapi sedikit salah kaprah), dapat dikatakan bahwa "pendidikan dengan bahasa perbuatan" (tarbiyat-un bi lisan -i l-hal) untuk anak adalah lebih efektif dan lebih mantab dari pada "pendidikan dengan bahasa ucapan"(tarbiyat-un bi lisan-I l-maqal)

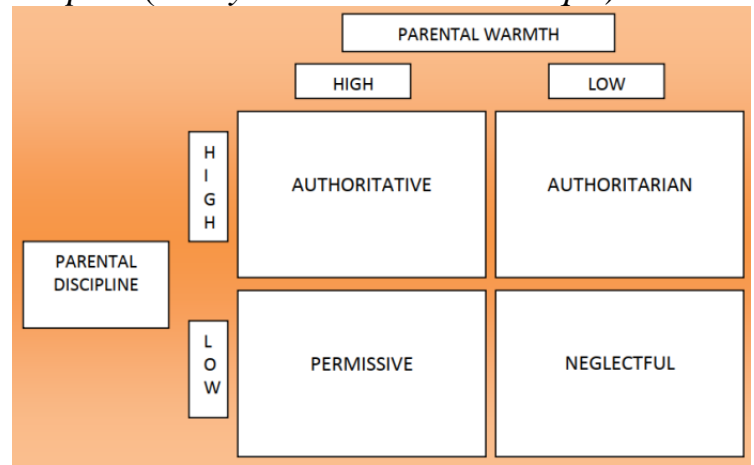

\section{Gambar 6 Matrix Pola Asuh dalam Keluarga}

Penelitian yang dilakukan oleh tim peneliti selama kurang lebih 5 bulan ini juga menghasilkan beberapa temuan yaitu :

a) Bahwa orang tua dengan latar belakang agama yang baik tidak menjadi jaminan akan menghasilkan anak dengan karakter yang baik pula.

Hal ini dikarenakan perilaku anak juga dipengaruhi oleh faktor lain seperti faktor lingkungan. Begitupun sebaliknya, anak yang tumbuh dalam keluarga dengan latar belakang agama yang kurang baik belum pasti akan memiliki karakter kurang baik pula selama lingkungannya mendukung untuk penguatan karakternya.

b) Bahwa lingkungan dengan karakteristik masyarakat agamis belum mampu menjamin tidak terjadinya tindak kenakalan remaja.

Hal tersebut dibuktikan dengan beberapa kasus kenakalan remaja justru berasal dari Kelurahan Krapyak yang notabene kelurahan dengan tingkat agama yang baik. Hal tersebut dibuktikan dengan sudah banyaknya kegiatan keagamaan yang rutin dilaksanakan di Kelurahan Krapyak seperti pengajian mingguan, TPQ, Madin dan lain sebagainya. 
c) Pola pendidikan agama yang ada di Kecamatan Pekalongan Utara adalah pola permisif yang memberikan kebebasan kepada anak tanpa pengawasan.

Hal tersebut dibuktikan dengan banyaknya kasus kenakalan remaja berasal dari keluarga dengan latar belakang agama yang tidak terlalu baik. Selain itu, kondisi orang tua yang sibuk bekerja membuat peran orang tua sebagai sentra pendidikan agama untuk anak tidak berjalan maksimal.

5.2. Desain Pendidikan Agama dalam Keluarga yang tepet guna Membangun Kemampuan Problem Solving Anak

Pendidikan agama dalam keluarga memiliki peranan yang penting dalam pembentukan karakter anak, salah satunya adalah membangun kemampan problem solving-nya. Kemampan problem solving merupakan kemampuan anak untuk mengolah setiap permasalahan dalam dirinya dan akan menjadi bekal penting dalam hidupnya. Anak dengan kemampuan problem solving yang baik akan berisiko sangat kecil terjerumus dalam tindakan kenakalan.

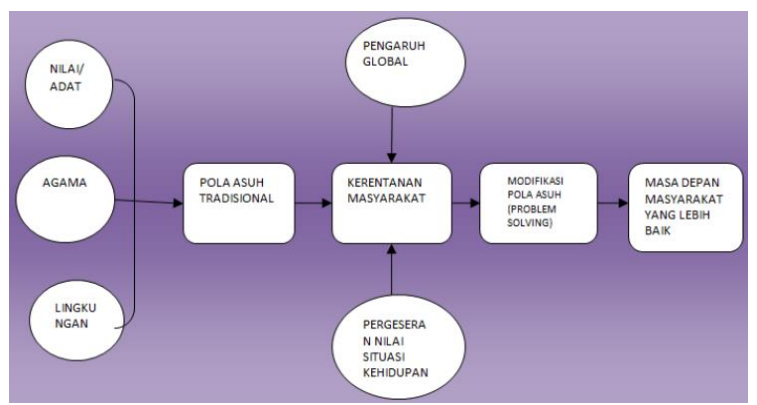

Gambar 7 Desain Pendidikan Agama untuk Meningkatkan Problem Solving

Darajat (1993), dalam bukunya "Peranan Agama dalam Kesehatan Mental", menyatakan bahwa fungsi agama adalah :

a) Agama memberikan bimbingan bagi manusia dalam mengendalikan dorongandorongan sebagai konsekuensi dari pertumbuhan fisik dan psikis seseorang.

b) Agama dapat memberikan terapi mental bagi manusia dalam menghadapi kesukarankesukaran dalam hidup. Seperti pada saat menghadapi kekecewaan-kekecewaan yang kadang dapat mengelisahkan batin dan dapat membuat orang putus asa. Di sini agama berperan mengembalikan kesadaran kepada Sang Pencipta.

c) Agama sebagai pengendali moral, terutama pada masyarakat yang mengahadapi problematika etis, seperti prilaku seks bebas (untuk kontek sekarang narkoba dan yang paling mutakhir syndrom politic, ekonomi dan budaya, pendidikan) (Darajat;1993)

Oleh karenanya, penting adanya menemukan pola pendidikan agama dalam kelarga yang tepat yang disesuaikan pula dengan karakteristik lingkungan tempat tinggal remaja tersebut guna membangun kemampuan problem solving-nya. Pada prinsipnya pola permisif tidak cocok diterapkan untuk pendidikan agama karena sifat pola permisif adalah segala aturan dan ketetapan keluarga di tangan anak. Apa yang dilakukan oleh anak diperbolehkan orang tua, orang tua menurut segala kemauan anak. Hal tersebut mengakibatkan perilaku anak yang bebas tanpa pengawasan.

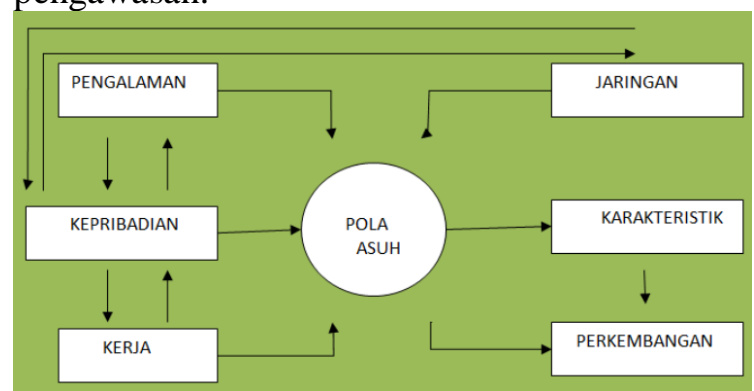

Gambar 8 Modifikasi Pola Asuh Orang Tua untuk Meningkatkan Problem Solving Anak

Pola yang cocok untuk keluarga dengan karakteristik agama yang kurang baik namun lingkungannya baik adalah pola situasional. Orang tua yang menerapkan pola pendidikan ini secara luwes disesuaikan dengan situasi dan kondisi yang berlangsung saat itu. Karena dengan didukung pendidikan agama yang diberikan oleh lingkungan tempat tinggalnya, anak mendapatkan pendidikan agama yang tidak diperolehnya di dalam keluarga. Sebaliknya, remaja yang tinggal pada keluarga dengan karakteristik pendidikan agama yang baik namun lingkungan tempat tinggalnya kurang baik harus diterapkan pola otoriter. Karena dengan pola ini, aturan orang tua harus ditaati oleh anak. Anak harus menurut dan tidak boleh membantah terhadap apa yang 
diperintahkan oleh orang tua. Hal tersebut sangat diperlukan agar pendidikan agama yang didapatkan di dalam keluarga tidak terpengaruh oleh lingkungan tempat tinggalnya.

\section{KESIMPULAN DAN SARAN}

\subsection{Simpulan}

Berdasarkan hasil dan pembahasan, maka dapat disimpulkan bahwa:

a) Pola pendidikan agama dalam keluarga di Kecamatan Pekalongan Utara sebagian besar telah menerapkan pola permisif. Ciri pola ini adalah anak diberikan kebebasan penuh dari orang tua. orang tua cenderung membiarkan sikap tidak hormat dari anak, tidak memiliki aturan yang tegas dan jarang menerapkan hukuman. Para peneliti telah menemukan bahwa pola pendidikan yang terlalu santai yang ditunjukkan oleh orang tua yang permisif dapat menyebabkan sejumlah hasil negatif. Anak-anak yang dibesarkan oleh orang tua yang permisif cenderung kurang disiplin diri, memiliki keterampilan sosial yang buruk, mungkin terlibat sendiri dan menuntut, dan merasa tidak aman karena kurangnya batasan dan bimbingan.

b) Desain pendidikan agama alternatif yang tepat menurut penelitian ini guna rangka membangun kemampuan problem solving adalah yang sesuai dengan kondisi sosial di mana remaja tersebut tinggal. Pola yang cocok untuk keluarga dengan karakteristik agama yang kurang baik namun lingkungannya baik adalah pola situasional. Orang tua yang menerapkan pola pendidikan ini secara luwes disesuaikan dengan situasi dan kondisi yang berlangsung saat itu. Karena dengan didukung pendidikan agama yang diberikan oleh lingkungan tempat tinggalnya, anak mendapatkan pendidikan agama yang tidak diperolehnya di dalam keluarga. Sebaliknya, remaja yang tinggal pada keluarga dengan karakteristik pendidikan agama yang baik namun lingkungan tempat tinggalnya kurang baik harus diterapkan pola otoriter. Karena dengan pola ini, aturan orang tua harus ditaati oleh anak. Anak harus menurut dan tidak boleh membantah terhadap apa yang diperintahkan oleh orang tua. hal tersebut sangat diperlukan agar pendidikan agama yang didapatkan di dalam keluarga tidak terpengaruh oleh lingkungan tempat tinggalnya.

\subsection{Saran}

Berdasarkan simpulan tersebut diatas, diberikan saran sebagai berikut.

a) Kepada pemerintah, diharapkan bisa memperhatikan dan menyelenggarakan kegiatan-kegiatan kemasyarakatan yang menambah wawasan dan keterampilan orang tua dalam mendidik. Di samping itu pemerintah harus memberikan suatu wadah yang jelas tidak saja dalam upaya mengintegrasikan teknologi ke dalam pendidikan Islam, tetapi bagaimana pula merespons generasi millenial yang semakin akrab dan dengan kemajuan teknologi, padahal derasnya pengaruh teknologi dan internet, telah memberikan dampak yang cukup signifikan bagi kalangan kaum muda muslim dalam menentukan peran mereka untuk merespons perubahan global.

b) Kepada sekolah/instansi pendidikan supaya lebih giat lagi menyelenggarakan kegiatan pendidikan parenting dan sering mengajak orang tua berkonsultasi tentang perkembangan dan pendidikan anak agar proses pendidikan anak dapat mendukung satu sama lain.

c) Kepada orang tua agar menjalin hubungan yang harmonis dengan anak (remaja), memperhatikan berbagai macam bentuk kebutuhan remaja, selalu mengarahkan dan bukan bersifat mendikte pada seluruh aktivitas remaja, memberikan gambaran positif pada setiap aktivitas remaja, mengajak remaja berdialog dalam menyelesaikan persoalan mereka, memberikan contoh-contoh atau suri tauladan yang baik, serta memberikan bentuk-bentuk pendidikan yang Islami.

d) Kepada pembaca pada umumnya, diharapkan memperhatikan pendidikan agama dalam keluarga, karena pada umumnya pendidikan agama itu berlangsung paling lama dalam keluarga. 
DAFTAR PUSTAKA

Agustiawati, I. (2014). Pengaruh Pola Asuh Orang Tua Terhadap Prestasi Belajar Siswa Pada Mata Pelajaran Akuntansi Kelas XII IPS di SMA Negeri 26 Bandung.

Andriyani, I. (2012). Pendidikan Islam dalam keluarga dan Masyarakat.

Argusni, Rika \& Sylvia, Ike. (2019). Pelaksanaan Model Problem Based Learninguntuk Meningkatkan Kemampuan Problem Solving Siswa Kelas XIIISSMAN16 Padang. Jurnal Sikola: Jurnal Kajian Pendidikan dan Pembelajaran, 1(1), 52-59.

Arikunto, Suharsimi. (2010). Prosedur Penelitian Suatu Pendekatan Praktek. Jakarta: Rineka Cipta.

Athiyah. (1993). Dasar-dasar Pokok Pendidikan Islam. Jakarta: Bintang Bulan.

Bahri, S. (2002). Strategi Belajar Mengajar. Jakarta: Rineka Cipta.

Daradjat, Zakiah. (1993). Peran Agama Dalam Kesehatan Mental. Jakarta : Haji Masagung

Daradjat, Zakiah. (1995). Pendidikan Islam dalam Keluarga dan Sekolah. Bandung: CV. Ruhama.

Daradjat, Zakiah. (2010). Membina Nilai-nilai Moral di Indonesia. Jakarta: Bulan Bintang.

Dimerman, S. (2009). Character is the Key: How to Unlock the Best in our Children and Ourselves. Mississauga, Canada: John wiley \& Sons Canada.

Elihami, E., \& Syahid, A. (2018). Penerapan Pembelajaran Pendidikan Agama Islam dalam Membentuk Karakter Pribadi yang Islami. Edumaspul: Jurnal Pendidikan, 2(1), 79-96.

Fachrudin. (2011). Peranan Pendidikan Agama dalam Keluarga Terhadap Pembentukan Kepribadian Anak-Anak. Jurnal Pendidikan Agama Islam -Ta'lim, 9(1), 116.

Hambali dan Arifin S. (1994). Pengaruh Kondisi Keluarga Terhadap Anak Berprilaku. Brelion Malang: Lemlit IKIP Malang.
Hamka. (1983). Tafsir Al-Azhar. Jakarta: Pustaka Pujiman.

Hawari, Dadang. (1996). Al-Qur'an: Ilmu Kedokteran Jiwa dan Kesehatan Jiwa Yogyakarta: PT Darma Bhakti Prima Yasa.

Hurlock, (1981). Perkembangan Anak. Jakarta : Erlangga

https://republika.co.id/berita/duniaislam/hikmah/17/05/13/opvcix396penguatan-pendidikan-agama-dalamkeluarga

Kartono, K. (2005). Patologi Sosial. Jakarta: PT Raja Grafindo.

Karyati, Sri. (2020). Profile Kecamatan Pekalongan Utara Tahun 2020.

Ki hadjar Dewantara. (tt). Karya Pendidikan Bagian Pertama, Cetakan Kedua. yogyakarta: majelis Luhur taman Siswa, h. $70-73$.

Mardiyah. (2015). Peran Orang Tua Dalam Pendidikan Agamaterhadap Pembentukan Kepribadian Anak. Jurnal Kependidikan, 3(2), 109-122.

Mufidah. (2008). Psikologi Keluarga Dalam Berwawasan Gender. Malang: UIN Malang Press.

Muhaimin. (2004). Paradigma Pendidikan Islam. Bandung: Remaja Rosdakarya.

Munawiroh. (2016). Pendidikan Agama Islam dalam Keluarga. EDUKASI: Jurnal Penelitian Pendidikan Agama dan Keagamaan, 14(3), 345-365.

Musmualim \& Miftah, Muhammad. 2018.Pendidikan Islam Di Keluargadalam Perspektif Demokrasi (Studi Pemikiran Hasan Langgulung Dan Abdurrahman An Nahlawi). Jurnal Penelitian, 10(2), 345398.

Nizar, Samsul. (2001). Pengantar Dasar-dasar Pemikiran Pendidikan Islam. Jakarta: Gaya Media Pratama.

Panggabean, Luhut. (1996). Penelitian Pendidikan, Bandung, Jurusan Pendidikan Fisika FPMIPA UPI.

Patnani. (2013). Upaya Meningkatkan Kemampuan Problem Solving Pada Mahasiswa. Jurnal Psikogenesis, 1(2), 130142.

Rahmi, Aulia. (2018). Pendidikan Agama Bagi Anak Dalam Keluarga di Gampong Aneuk 
Galong Baro, Aceh Besar. FITRAH: Jurnal Kajian Ilmu-ilmu Keislaman, 4(1), 129140.

Rohman, Taufiqur. (2018). Model Pendidikan Agama Dalam Keluarga Muslim Di Desa Pulutan Kecamatan Sidorejo Kota Salatiga. Edudena, 2(2), 181-193.

Seminar peran perempuan dalam membina akhlak dan moral anak, jakarta, 12 September 2014.

Sugiyono. (2015). Metode Penelitian Kuantitatif, Kualitatif, dan R\&D Bandung: ALFABETA.

Ulyan, Mohammad. (2020). Pendidikan Islam dalam Keluarga Sebagai Solusi Degradasi Kejujuran. Nur El-Islam, 7(1), 26-51.

Unayah N \& Sabarisman M. (2015). Fenomena Kenakalan Remaja dan Kriminalitas.

Sosio Informa, 1(2), 20-32.

Willis, S.S. (2014). Remaja dan Masalahnya. Bandung: Alfabeta.

Yusri, Nur'Aisyiah \& Maris, Sonya Regina. (2017). Hubungan Dukungan Sosial Teman Sebaya dengan Problem Solving Siswa SMP. Al-Qalb: Jurnal Psikologi Islam, 9(2), 118-126 